\title{
Modal Sosial Dalam Pengembangan Madu Kelulut Sebagai Komoditas Ekonomi Dan Pariwisata Di Kecamatan Lubuk Kabupaten Bangka Tengah
}

\author{
Luna Febriani ${ }^{1}$, Putra Pratama Saputra ${ }^{2}$ \\ Jurusan Sosiologi, Fakultas Ilmu Sosial dan Ilmu Politik, Universitas Bangka Belitung \\ lunafebriani.lf@gmail.com dan putraps92@gmail.com
}

\begin{abstract}
Kelulut Honey is one of the new commodities in Lubuk Subdistrict and has been developed by many local people. The development of this honeyed honey indirectly affects the income sector for the community and also has an impact on the development of tourism in the village. This study aims to identify and analyze social capital that is used by the Lubuk Sub-district community in developing the commodity of kelulut honey. The research method used to conduct this study is a qualitative method that emphasizes the deepening of a meaning and phenomenon. In analyzing this research, the concept and theory of social capital will be used by Robert Putnam. The results of the study show that there is the use of social capital in the effort to develop kelulut honey as a sector of the community's income and tourism sector. Social capital used includes: trust, networks and norms of the local community, so that the optimal use of social capital makes kelulut honey as a commodity in Lubuk District.
\end{abstract}

\section{Keywords : Kelulut Honey, Social Capital, and Bangka Tengah}

\begin{abstract}
ABSTRAK
Madu Kelulut merupakan salah satu komoditas baru yang ada di Kecamatan Lubuk dan mulai banyak dikembangkan oleh masyarakat setempat. Pengembangan madu kelulut ini secara tidak langsung berdampak kepada sektor pendapatan bagi masyarakat dan berdampak juga bagi perkembangan pariwisata di desa tersebut. Penelitian ini bertujuan untuk mengidentifikasi dan menganalisis modal sosial yang di daya gunakan oleh masyarakat Kecamatan Lubuk dalam mengembangkan komoditas madu kelulut. Metode penelitian yang digunakan untuk melakukan kajian ini adalah metode kualitatif yang menekankan pada pendalaman suatu makna dan fenomena. Dalam menganalisis penelitian ini akan digunakan konsep dan teori modal sosial dari Robert Putnam. Hasil penelitian menujukkan bahwa adanya penggunaan modal sosial dalam upaya pengembangan madu kelulut sebagai sektor pendapatan masyarakat dan sektor pariwisata. Modal sosial yang digunakan antara lain: kepercayaan, jaringan dan norma masyarakat setempat, sehingga penggunaan modal sosial yang optimal ini menjadikan madu kelulut sebagai komoditas di Kecamatan Lubuk.
\end{abstract}

Kata Kunci: Madu Kelulut, Modal Sosial, dan Bangka Tengah. 


\section{PENDAHULUAN}

Provinsi Kepulauan Bangka Belitung merupakan salah satu provinsi di Indonesia yang memiliki keberlimpahan atas sumberdaya alamnya, yakni timah. Komoditas timah yang dihasilkan oleh Provinsi Kepulauan Bangka Belitung ini menjai pemasok kebutuhan utama akan timah baik di ranah nasional maupun internasional. Keberlimpahan akan timah yang dimiliki oleh Provinsi Kepulauan Bangka Belitung menjadikan sektor pertambangan sebagai sektor unggulan. Hal ini menjadikan hampir segenap masyarakat Provinsi Kepulauan Bangka Belitung menjadikan timah sebagai sumber pendapatan utama kehidupan mereka.

Di Provinsi Kepulauan Bangka Belitung banyak dijumpai proses pertambangan timah mulai pertambangan yang digarap oleh perusahan maupun pertambangan yang digarap oleh masyarakat atau yang dikenal dengan sebutan Timah Inkonvensional (TI). Penambangan timah di Provinsi Kepulauan Bangka dilakukan sejak jaman VOC hingga sekarang. Seiring proses penambangan yang terus dilakukan dari zaman dahulu menjadikan ketersediakan akan timah ini semakin menipis. Hal ini kemudian menjadikan masyarakat Kepulauan Bangka Belitung melirik sektor lain untuk sistem penghidupan mereka.

Sektor yang digeliatkan oleh pemerintah dan masyarakat Provinsi Kepulauan Bangka Belitung untuk menggantikan sektor pertambangan adalah sektor pariwisata, perkebunan dan peternakan. Salah satu desa yang giat mengembangkan peternakan adalah Kecamatan Lubuk Kabupaten Bangka Tengah. Kecamatan Lubuk merupakan salah satu kecamatan yang berada dalam wilayah administratif Provinsi Kepulauan Bangka Belitung, tepatnya di Kabupaten Bangka Tengah. Penduduk di Kecamatan Lubuk ini sebagian besar menggantungkan kehidupan mereka pada sektor pertambangan timah, terutama Tambang Inkonvensional (TI). Selain bergantung pada sektor pertambangan, sektor perdaganan dan kehutanan serta perkebunan juga menjadi sektor andalan masyarakat dalam menggantungkan hidupnya.

Keberadaan timah di Kecamatan Lubuk perlahan mulai menipis, oleh karena itu masyarakat mulai menggeliatkan sektor lain untuk dapat tetap bertahan hidup, salah satu sektor yang kembali digeliatkan adalah sektor peternakan dan pembudidayaan madu kelulut. Madu kelulut merupakan hasil produksi yang dikeluarkan oleh lebah kelulut. Berbeda dengan lebah biasa, lebah kekulut memiliki ukuran fisik badan yang lebih kecil ketimbang lebah biasa dan madu kelulut lebih jinak ketimbang madu biasa. Selain itu madu yang dihasilkan oleh lebah kelulut memiliki rasa yang tidak jauh berbeda dengan lebah biasa, tapi diawal panen lebah kelulut menghasilkan madu yang masam manis. Madu kelulut juga memiliki khasiat yang hampir sama dengan khasiat madu biasa, yakni untuk kesehatan dan bisa juga untuk kecantikkan.

Pembudiayaan madu kelulut yang dilakukan masyarakat memiliki dampak di bidang ekonomi, terutama di kelompok masyrakat kecil dan menengah. Pembudidayaan madu kelulut menghasilkan sumber ekonomi bagi masyarakat melalui penjualan hasil dari madu kelulut itu sendiri. Selain itu, pembudidayaan madu kelulut ini juga memberikan efek bagi sektor pariwisata bagi Kecamatan Lubuk, dimana dengan adanya proses pembudiyaan madu kelulut menjadikan banyak orang di luar Kecamatan Lubuk mengunjungi desa ini untuk melihat dan menikmati secara langsung sensasi yang ditawarkan oleh madu kelulut.

Berdasarkan fenomena diatas, peneliti merasa tertarik untuk mengkaji tentang modal sosial seperti apa yang dimobililasi oleh masyarakt setempat sehingga menjadikan madu kelulut berkembang sebagai komoditas masyrakat Kecamatan Lubuk dalam Pengembangan Madu Kelulu. Penelitian ini diharapkan dapat memberi gambaran tentang proses pengembangan madu kelulut dan potensi dalam pengembangannya. 


\section{METODE PENELITIAN}

Penelitian merupakan suatu kegiatan untuk memperoleh jawaban atau penjelasan mengenai suatu fenomena yang diamati. Metode yang digunakan dalam penelitian ini adalah metode penelitian kualitatif deskriptif. Tujuannya untuk menemukan data mendalam yang mengandung makna, serta menggambarkan kondisi sosial secara deskriptif dan faktual. Data kualitatif dinyatakan dalam bentuk kalimat dan uraian. Analissi data kualitatif dilakukan dengan jalan bekerja dengan data, mengorganisasikan data, memilahnya menjadi satuan yang dapat dikelola, mengintergrasikannya, mencari dan menemukan pola, menemukan apa yang penting dan apa yang dipelajari dan memutuskan apa yang dapat diceritakan kepada orang lain (Moleong, 20017: 248).

Adapun teknik pengumpulan data dilakukan dengan cara:

1. Wawancara, Wawancara merupakan teknik pengumpulan data dengan mengajukan pertanya-pertanyaan kepada informan. Teknik wawancara yang digunakan adalah wawancara tidak terstruktur yang mana seorang peneliti bebas menentukan fokus nmasalah wawancara, kegiatan wawancara mengalir seperti dalam percakapan biasa, yaitu mengikur dan menyesuaikan diri dengan kondisi informan. Teknik penentuan informan yang digunakan adalah purposive sampling. Purposive sampling merupakan teknik pengambilan sampel bertujuan dengan menggunakan kriteriakriteria tertentu sesuai kebutuhan data. Kriteria untuk informan dalam penelitian ini, diantaranya pemerintah kabupaten, perwakilan Desa, masyarakat yang terlibat dalam pembudidayaan madu kelulut, dan orang yang mengunjungi tempat pembudidayaan madu kelulut.

2. Observasi, yang dilakukan dalam penelitian ini adalah observasi partisipatif. Peneliti sebagai pengamat melakukan pengamatan terhadap fenomena-fenomena yang terjadi di lapangan dan mencatatnya sebagai bahan atau data untuk kemudian dilakukan analisis. Observasi dilakukan dengan mengamati proses pembudidayaan madu kelulut serta mengamati kegiatan pariwisata di lokasi madu kelulut.

3. Dokumentasi yaitu teknik pengumpulan data dengan cara mencatat data yang telah ada di tempat penelitian dan melakukan penelusuran dokumen-dokumen. Dokumen yang dimaksud dapat berupa jurnal, buku, dan laporan yang dinilai relevan dengan kebutuhan data penelitian.

Penelitian ini mengambil lokasi di Kecamatan Lubuk Kabupaten Bangka Tengah. Pemilihan lokasi ini didasarkan atas kondisi masyarakat setempat. Kecamatan Lubuk merupakan desa pertama yang menginisiasi pembudidayaan madu kelulut dalam pengembangan di sektor peternakan. Namun selain untuk peternakan, madu pembudidayaan madu kelulut memberikan dampak terhadap sektor pariwisatanya. Banyak orang yang berkunjung ke Kecamatan Lubuk guna untuk melihat dan menikmati madu kelulut secara langsung, Pembudidayaan madu kelulut saat ini sudah dikembangkan oleh masyarakat terutama melalui kelompok usaha mikro kecil dan menengh (UMKM). Oleh karena itu peneliti tertatik mengambil lokasi ini sebagai lokasi penelitian.

\section{III.HASIL PENELITIAN DAN PEMBAHASAN}

Muncul dan berkembangnya madu kelulut di Kecamatan Lubuk Kabupaten Bangka Tengah tidak dapat dilepaskan dari inisiasi masyarakat setempat untuk mengembangkan atau memunculkan suatu usaha. Proses kemunculan dan pengembangan madu kelulut ini dimulai dari inisiatif seorang warga Kecamatan Lubuk, yakni Bapak Muksin Berawal dari aktor tersebut yang saat itu sedang menonton siaran kartun di televisi (Upin dan Ipin) 
dimana pada tayangan tersebut ada menayangkan pembudidayaan madu kelulut di hutan. Menurtunya, bukan hal yang mustahil jika ini dilakukan di daerahnya, oleh karena itu pasca menonton tayangan ini MuksinBapak Muksin langsung pergi ke hutan untuk mencari madu kelulut dan menyiapkan peralatan yang dibutuhkan untuk membudidayakan madu kelulut.

Setelah mendapatkan madu kelulut di hutan, Bapak kemudian membuat perlengkapan untuk menunjang budidaya madu kelulut. Adapun peralatan yang dibutuhkan untuk budidaya antara lain: rumah (atau yang sering disebut toping) untuk madu, kayu atau batang untuk menopang toping, serta alat untuk memanennya. Upaya membudidayakan madu kelulut yang dilakukan oleh Bapak Muksin ini kemudian memberikan hasil yang memuaskan, seperti perolehan madu dan pendapatan dari hasil penjualan madu tersebut. Keberhasilan ini kemudian diikuti oleh beberapa masyarakat di Kecamatan Lubuk yang mulai beralih untuk membudidayakan madu kelulut. Sehingga, melihat banyaknya minat masayarakat setempat dalam membudidayakan madu kelulut ini, mereka kemudian membuat kelompok tani Karomah. Kelompok tani Karomah ini diharapkan dapat menjadi wadah bagi para pembudidaya dalam menyalurkan aspirasi dan memudahkan dalam mengelola madu kelulut serta memperoleh bantuan dari untuk budidaya madu kelulut.

Tingginya minat dan animo masyarakat Lubuk akan budidaya madu kelulut menjadikan Dinas Kehutanan Kabupaten Bangka Tengah memainkan perannya untuk mendukung kegiatan tersebut, hal ini dapat dilihat dari dimana dinas melakukan kegiatan pelatihan dan pendampingan kepada masyarakat terkauit pembudidayaamn tersebut. Pelatihan dan pendampingan tersebut berisikan penyampaian informasi tentang pembudidayaan madu kelulut, termasuk bagaimana pengelolaan hingga pemasarannya. Selain itu, dalam rangka mendukung upaya budidaya madu kelulut ini, Pemerintah menetapkan salah satu hutan yang ada di pulau di Kecamatan Lubuk untuk dijadikan tempat khusus pembudidayaan madu kelutut, yakni pulau Ranggau. Namun, akhir-akhir ini hutan tersbut tidak lagi digunakan sebagai lokasi pembudidayaan madu kelulut, hal ini dikarenakan adanya konflik dalam pengelolaaannya. Sehingga, lokasi budidaya madu kelulut saat ini dilakukan di masingmasing rumah atau lokasi yang telah ditetapkan para pembudidayanya sendiri.

Saat ini, terdapat sebanyak 40 masyarakat telah mengembangkan dan membudidayakan serta memasarkan madu kelulutnya masing-masing. Masing-masing dari mereka memiliki merk hasil produksi yang mana hasilnya sudah mereka pasarkan baik di Kabupaten Bangka Tengah itu sendiri maupun di luar Kabupaten Bangka Tengah, seperti Kota Pangkalpinang, Lampung hingga Pulau Jawa. Berdasarkan hasil penelitian, madu kelulut memiliki prospek yang menghasilkan, hal ini mengingat madu merupakan madu kelulut merupakan sesutau yang memiliki nilai jual serta madu kelulut masih minim ditemui.

\section{A. Pemberdayaan Masyarakat Melalui Madu Kelulut}

Pemberdayaan masayraakat merupakan upaya meningkatkan harkat dan martabat lapisan masayraakat yang dalam kondisi sekarang tidak mampu untuk melepaskan diri dari perangkap kemisikinan dan keterbelakangan,. Dengan kata lain, memberdayakan adalah memampukan dan memandirikan masyarakat (Theresia: 93). Konsep pemberdayaan menekankan pada proses memberikan kemampuan kepada masayrakat agar menjadi berdaua, mendorong atau memotivasi individu agar mempunyai kemampuan atau keberdayan untuk menentukan pilihannya.

Proses pemberdayaan pada masayarakat di Kecamatan Lubuk terlihat dari bagaimana masayrakat dapat berpikir kreatif untuk mengembangkan kemampuannya dalam memberikan peluang dan inovasi terkait kehidupan ekonomi mereka dan bagaiman 
mereka menentukan pilihan mereka. Proses pemberdayaan ini dapat dilihat dari tiga sisi, yakni:

1. Enabling, merupakan menciptakan suasana atau iklim yang memungkinkan potensi masyarakat berkembang. Proses enabling dapat diamati dari ni merupakan tahapan awal dari proses pemberdayaan, yang mana masayrakat mulai berinovasi dan menciptakan peluang yang sebelumnya tidak ada dalam masyarkat tersebut. Tahapan ini masyarakat menentukan sendiri jenis usahanya, kondisi wilayah yang pada gilirannya dapat menciptakan lembafa dan sitem pelayanan dari, oleh dan untuk masayrakat. Penciptaan peluang ini dimulai dari ketika Muksin mendapatkan inspirasi untuk membudidayakan madu kelulut dengan cara mencari madu kelulut di hutan serta membuat perlengkapan untuk proses pemberdayaan tersebut. Peluang ini kemudian diikuti oleh beberapa masyarkat yang ada, sehingga saat ini terdapa 40an orang masyarakat di Kecamatan Lubuk yang sudah mulai membudidayakan madu kelulut. Selain itu, pada tahapan ini dibentuk pula organisasi atau lembaga yang menaungi kelompok pembudidaya madu kelulut di kecamatan Lubuk, tujuannya untuk mewadahi aspirasi para pembudidaya madu kelulut serta untuk membantu mengembangkan madu kelulut.

2. Empowering, yang merupakan proses memperkuat potensi atau daya yang dimiliki masyarakat. Setelah penciptaan peluang, maka tahapan penting selanjutknya dari proses pemberdayaan adalah upaya pemberdayaan ekonomi rakyat. Tahapan ini merupakan tahapan dimana kemampuan individu bersenyawa dalam masyarakat dan membangun keberdayaan masayrakat tersebut. Pemberdayaan ekonomi masyarakat ini dapat dilihat dari mulai berdayanya atau mandirinya masyarakat Kecamatan Lubuk dalam membudidayakan madu Kelulut. Terdapat 40an masyarakat yang mulai fokus dalam proses pengembangan ini, kebanyakan dari pembudidaya ini mengembangkan madu kelulut mulai dari pembudidayaan hingga proses pemasarannya. Hasil madu kelulut ini sudah mereka pasarkan di Kecamatan Lubuk, Kota Pangkalpinang, hingga Pulau Jawa dan Lampung. Keuntungan yang didapatkan cukup signifikan, dimana satu botol madu kelulut dijual dengan harga Rp. 100.000,- dengan masa panen dua minggu yang mana satu kali panen dapat menghasilkan madu kurang lebih 11 liter. Hal ini tentunya menjadikan prospek ekonomi yang mencerahkan bagi para pembudidaya madu kelulut.

3. Protecting atau melindungi, dimana harus dicegah yang lemah menjadi bertambah lemah, oleh karena kurangberdayaan dalam menghadapi yang kuat. Proses protecting ini salah satunya dapat dilihat dari pembentukkan kelompok tani Karomah yang mewadahi para pembudidaya madu kelulut tersebut. Tujuannya adalah untuk menampung aspirasi para pembudidaya dalam membantu serta melindungi pembudidaya madu kelulut. Selain itu proses protecting atau melindungi ini juga dapat dilihat dari peran serta dinas Kehutanan Kabupaten Bangka Tengah dalam mengakomodir dan membantu proses pengembangan dan pembudidayaan madu kelulut.

Dari hasil penelitian, didapat kesimpulan bahwa pemberdayaan yang terjadi pada proses pengembangan madu kelulut ini merupakan pemberdayaan sebagai proses perubahan. Pemberdaayaan sebagai proses perubahan ini terjadi seiring berkembangnya kehidupan manusia baik perubahan kondisi fisiknya, maupun perubahan yang terjadi akibat ulat atau perilaku manusia di 
kehidupan sehari-harinya. Hal ini kemudian menghadirkan akibat berubahnya pula kebutuhan-kebutuhan dala masyarakat. Sehubungan dengan terjadinya pemberdayaan sebagai proses perubahan, terdapat beberapa faktor yang mendorong terjadinya perubahan tersebut, yakni:

1. Terjadinya persaingan antar individu atau masyarakat yang senantiasa ingin memenuhi kebutuhannya.

2. Akibat persaingan tersebut, terjadinya kerusakan-kerusakan fisik dan lembaga akibat persaingan tersebut.

3. Adanya keinginan manusi untuk melakukan modifikasi tentang kebutuhannya, baik untuk menghadapi masalah jangka pendek maupun jangka penjang.

Dalam konteks masyaarkat Kecamatan Lingkuk terkait pengembangan madu Kelulut, faktor pendorong terjadinya pemberdayaan diawali adanya persaingan antar individu untuk memenuhi kebutuhannya. Sebagaimana yang diketahui, masayarakat Kecamatan Lubuk banyak yang berprofesi sebagai penambang timah inkonvensional, sementara itu persedian timah akhir-akhir ini semakin menipis dan mulai banyaknya dilakukan pengawasan serta pengamanan (razia) akan keberadaan timah inkonvensional tersebut. Oleh karena itu, persaingan antar masuyarakat untuk memenuhi kebutuhan hidupnya semakin meningkat. Disisi lain, akibat dari persaingan dan penambangan timah tersebut, telah terjadi kerusakan-kerusakan lingkungan pada masyarkat tersebut. Hal inilah yang kemudian memicu inovasi masyarakat Kecamatan Lubuk untuk membuat atau menemukan sesuatu yang baru dalam rangka memenuhi kebutuhan hidupnya, yakni budidya madu kelulut. Sehingga, saat ini budidaya madu kelulut sudah mulai menjadi penopang ekonomi masyarakat Kecamatan Lubuk.

Pemberdaayaan sebagai proses perubahan memerlukan ide, produk, gagasan, metode, peralaatan dan teknologi.Selain itu, pemberdayaan ini juga mensyaratkan fasilitator yang kompeten dan memiliki integritas tinggi. Fasilitatornya dapat terdiri dari aparat pemerintah, aktivis LSM serta tokoh masyarkat itu sendiri. Pada kasus pemberdayaan masayarkat Lubuk, peran pemerintah sebagai pendamping tidak dapat dilepaskan, hal ini terlihat dimana ketika masayrakat mulai menggalakkan budidaya madu kelulut pemerintah melalui Dinas Kehutanannya memberik informasi dan wawasan tentang hal tersebut dalam bentuk seminar yang mendatangkan narasumber yang kompeten. Selain itu, proses pendampingan juga ditunjukkan dengan cara pendampingan-pendampingan dalam mempermudah izin serta pendampingan proses packagingnya.

\section{B. Modal Sosial Pengembangan Madu Kelulut}

Pemberdayaan madu kelulut yang ada di Kecamatan lubuk, tidak dapat dilepaskan dari modal sosial yang digerakkan oleh masyarakat tersebut. Modal sosial menurut Coleman merupak varian entitas, terdiri dari beberapa struktur sosial yang memfasilitasi tindakan dari para pelakunya, apakah dala bentuk personal atau korporasi dalam struktur sosial. Dengan kata lain, modal sosial merujuk pada bagaimana kemampuan masayarakat dalam suatu entitas atau kelompok untuk bekerjasama membangun suatu jaringan untuk mencapai tujuan bersama. Adapun modal sosial yang terdapat pada proses pemberdayaan masyarakat Kecamatan Lubuk adalah:

1. Partisipasi Dalam Suatu Jaringan

Dalam partisipasi ini, modal sosial tidak dibangun hanya dari satu individu saja, melainkan terletak pada kecenderungannya yang tumbuh dalam suatu kelompok untuk bersosialisasi sebagai bagian penting dari nilai-nilai yang melekat. Partisipasi dalam pembudidayaan madu kelulut ini ditunjukkan dengan bagaimana proses pembudidayaan madu kelulu yang awalnya hanya dilakukan oleh Muksin, kemudian diikuti oleh masyarakat setempat sehingga sampai saat ini terdapat 40an masayarakat yang 
melakukan budidaya tersebut dan terbentuklah kelompok Tani Karomah yang menaungi para pembudidaya madu kelulut. Dari sinilah terbangun hubungan dan interaksi antar masayarakaat dimana hubungan tersebut dapat membentuk sebuah jaringan baru yang menyambungkan jaringan-jaringan lain yang dimiliki oleh setiap individu.

2. Reciprocity

Modal sosial senantiasa diwarnai oleh kecenderungan saling tukar kebaikan antar individu dalam suatu kelompok atau dalam kelompok itu sendiri. Hubunga ini juga terjadi antar individu yang terlibat dalam proses pembudidayaan madu kelulut, dimana setiap individu yang memiliki usaha pembudidayaan yang cukup besar dan sukses maka mereka tidak segan-segan untuk membantu atau mengajari individu yang baru memulai usahanaya atau usaha yang cenderung kecil. Dengan kata lain, tidak ada persaingan dalam kelompok masyarakat ini, melainkan hubungan yang saling membantu yang ada pada kelompok ini.

3. Trust

Trust atau rasa percaya adalah suatu bentuk keinginan untuk mengambil resiko dalam hubungan sosial yang didasari oleh perasaan yakin bahwa yang lain akan melakukan sesuatu seperti yang diharapkan dan akan senantiasa bertindak pada suatu pola tindakan yang saling mendukung, paling tidak tidak merugikan diri dan kelompoknya. Trust ini terlihat dari kepercayaan para pembudidaya mengembnagkan madu kelulut, meskipun harus mengeluarkan modal yang cukup besar (kurang lebih minimal Rp. 350.000,-/ topping madu kelulut) tapi pembudidaya optimis budidaya ini akan memberikan hasil yang optimal.

4. Norma Sosial

Norma sosial berperan dalam mengontrol bentuk perilaku yang tumbuh dalam masyarakat. Norma sosial ini mengacu pada aturan-aturan yang ada pada masyarakat tersebut. Masyarakat
Kecamatan Lubuk merupakan masyrakat yang masih dapat dikatakan tradisional atau dengan kata lain merupakan masayarakat yang memiliki solidaritas organik. Masyarkat pada tipe ini memiliki ciri diantranya: solidaritas yang tinggi, kolektifitas tinggi dan individualitas yang rendah, serta normanorma sosial masih menjadi acuan dalam bertindak. Salah satu norma sosial yang kentara terasa di masyakarat Lubuk adalah bagaimana solidaritas mereka masih tinggi yang terlihat dukungan yang diberikan masyarkat kepada pembudidaya madu kelulut ini, misalnya: masyarakat akan membantu mempromosikan langsung madu kelulut para pembudidaya dari Kecamatan Lubuk ke orang-orang banyak, selain itu bentuk dukungan juga dapat dilihat dari masyarakat tidak pernah mengganggu aktivitas budidaya tersebut.

5. Tindakan yang Proaktif

Merupakan keinginan yang kuat dari anggota kelompok untuk tidak saja berpartisipasi tetapi senantiasa mencari jalan bagi keterlibatan mereka dalam suatu kegiatan masyarakat. Tindakan proaktif dapat dilihat dari bagaimana para pembudidaya melakukan promosi dengan cara bekerjasama dengan masyarkat atau lembaga-lemabag yang sedang melakukan kegiatan atau event, kemudian mereka menggelar bazar atau pameran hasil produksi pada kegiatan. Hal ini tidak dapat dilepaskan dari kendala utama yang dihadapi oleh para pembudidaya ini adalah pemasaran dan promosi. Sehingga dengan adanya pameran atau bazar ini dapat membantu para pembudiadaya dalam mengenalkan serta memasarkan hasil madu kelulut mereka.

\section{IV.KESIMPULAN}

Berdasarkan hasi identifikasi dan temuan dilapangan tentang proses pembudidayaan madu Kelulut di Kecamatan Lubuk Kabupten Banggka Tengah, Propinsi Kepulauan Bangka Belitung, sejauh ini dapat ditarik kesimpulan bahwa terdapat 
proses pemberdayaan dalam hal budidaya madu kelulut, yakni:

1. Enabling, merupakan menciptakan suasana atau iklim yang memungkinkan potensi masyarakat berkembang. Penciptaan peluang ini dimulai dari ketika Muksin mendapatkan inspirasi untuk membudidayakan madu kelulut dengan cara mencari madu kelulut di hutan serta membuat perlengkapan untuk proses pemberdayaan tersebut.

2. Empowering, yang merupakan proses memperkuat potensi atau daya yang dimiliki masyarakat. Pemberdayaan ekonomi masyarakat ini dapat dilihat dari mulai berdayanya atau mandirinya masyarakat Kecamatan Lubuk dalam membudidayakan madu Kelulut. Terdapat 40an masyarakat yang mulai fokus dalam proses pengembangan ini, kebanyakan dari pembudidaya ini mengembangkan madu kelulut mulai dari pembudidayaan hingga proses pemasarannya. Hasil madu kelulut ini sudah mereka pasarkan di Kecamatan Lubuk, Kota Pangkalpinang, hingga Pulau Jawa dan Lampung. Keuntungan yang didapatkan cukup signifikan, dimana satu botol madu kelulut dijual dengan harga Rp. 100.000,- dengan masa panen dua minggu yang mana satu kali panen dapat menghasilkan madu kurang lebih 11 liter. Hal ini tentunya menjadikan prospek ekonomi yang mencerahkan bagi para pembudidaya madu kelulut.

3. Protecting atau melindungi, dimana harus dicegah yang lemah menjadi bertambah lemah, oleh karena kurangberdayaan dalam menghadapi yang kuat. Proses protecting ini salah satunya dapat dilihat dari pembentukkan kelompok tani Karomah yang mewadahi para pembudidaya madu kelulut tersebut. Tujuannya adalah untuk menampung aspirasi para pembudidaya dalam membantu serta melindungi pembudidaya madu kelulut. Selain itu proses protecting atau melindungi ini juga dapat dilihat dari peran serta dinas Kehutanan Kabupaten Bangka Tengah dalam mengakomodir dan membantu proses pengembangan dan pembudidayaan madu kelulut.

Dalam mengembangkan proses pembudidayaan madu kelulut, masyarkat memobilisaisi modal sosial yang ada yang mana gunanya untuk mencapai tujuan yang telah ditetapkan sebelumnya. Adapun modal sosial yang dimobilisasi masyarakat, yakni: partisipasi dalam jaringa, trust atau kepercayaan, resiprocity, norma sosial dan tindakan proaktif. Mobiliasi modal sosial ini diyakini dapat membantu masyarakat dalam mengembangkan madu kelulut hingga saat ini.

\section{UCAPAN TERIMA KASIH}

Terima kasih yang sebesar-besarnya kami haturkan kepada Universitas Bangka Belitung dan Lembaga Penelitian dan Pengabdian Masyarakat (LPPM) Universitas Bangka Belitung yang telah memberi dukungan baik dukungan pembiayaan maupun dukungan moral terhadap penelitian ini.

\section{DAFTAR PUSTAKA}

[1] Afrizal. (2014). Metode Penelitian Kualitatif: Sebuah Upaya Mendukung Penggunaan Penelitian Kualitatif dalam Berbagai Disiplin Ilmu. PT. Rajagrafindo Persada, Depok.

[2] Bungin, Burhan. (2007). Penelitian Kualitatif. Kencana, Surabaya.

[3] Gusta Prima, Anugrah. (2017). Evaluasi Pemerekan Pariwisata Provinsi Kepulauan Bangka Belitung (Tesis). Universitas Gadjah Mada, Yogyakarta.

[4] Hasbullah, Joussairi. (2006). Social Capital (Menuju Keunggulan Budaya Masyarakat Indonesia). MR United Press, Jakarta.

[5] Idrus, Muhammad. (2009). Metode Penelitian Ilmu Sosial Pendekatan 
Kualitatif dan Kuatitatif. Erlangga, Yogyakarta.

[6] Nurfianti, Zulaikha. (2014). Persepsi Stakeholder Pariwisata Terhadap Perubahan Budaya Suku Sekak di Desa Kumbung dalam Hubungannya dengan Upaya-upaya Peningkatan Daya Tarik Wisata di Kabupaten Bangka Selatan (Tesis). Universitas Gadjah Mada, Yogyakarta.
[7] Raho, bernard. (2007). Teori Sosiologi Modern. Prestasi Pustaka Publisher, Jakarta.

[8] Theresia, dkk. (2014). Pembangunan Berbasis Masyarakat: Acuan Bagi Praktisi, Akademisi dan Pemerhati Pengembangan Masyarakat. Alfabeta, Bandung. 